\title{
Economic Analysis of Cost and Returns in Male Buffalo Calves Farming for Meat Production in Selected Districts of Tamil Nadu, India
}

\author{
V. Senthilkumar*, V. Palanichamy and R. Chitra \\ Department of Animal Husbandry Economics, Veterinary College and Research Institute, \\ Namakkal, Tamil Nadu Veterinary and Animal Sciences University, India \\ *Corresponding author
}

\section{Keywords \\ Male buffalo calves, \\ Fixed investment, \\ Gross cost, Net \\ return and $\mathrm{BCR}$}

Article Info

Accepted:

15 August 2020

Available Online:

10 September 2020

\section{A B S T R A C T}

India's livestock sector is one of the largest in the world with a holding of 11 per cent of world livestock population. In species wise meat contribution during the year 201819, the buffalo meat contributes 19.05 per cent and 13.30 lakh tonnes of buffalo meat annually exported by India. In India, male buffalo calves are considered as burden and left as such as stray animals. The rearing of male buffalo calves for meat production is an economically viable enterprise as integration with crop and fodder in some districts of Tamil Nadu near by border state of Kerala. Coimbatore, Theni and Kanyakumari districts were purposively selected for the present study. From each of the selected districts, 20 male buffalo calves rearer were selected randomly, covering a total of 60 male buffalo calves farmers for this study. Fixed investment, fixed cost, variable and gross cost and gross return and net return; benefit cost ratio, break even output and margin of safety also were calculated for small, medium and large farm category. Major components of total investment in large per farm was construction of shed (85.02 per cent). Total fixed cost per farm is higher in medium farm (6.75 per cent), large farm (4.71 per cent) and small farm (00.10 per cent). Average variable costs incurred per animal in medium farm was higher in cost of bull calves (68.43 per cent), followed by cost of concentrate (26.06 per cent), cost of green fodder cultivation $(0.12$ per cent), cost of dry fodder (1.96 per cent), labour wages (1.13 per cent), deworming charges ( 1.43 per cent), Vaccination charges ( 0.14 per cent), electricity expenses $(0.01$ per cent) and miscellaneous charges ( 0.71 per cent). It was found that net return per farm was Rs.4,60,188.00 (large), Rs.1,08,806.60 (medium) and Rs.23,548.46 (small). Net return per animal in large farm was Rs.12,871.73, medium farm for Rs.11,832.60 and small farm for Rs.7,563.9. It could be found that the benefit cost ratio of male buffalo calves farming was 1:1.22, 1:1.29 and 1:1.40 in small, medium and large farms, respectively. The average break even output was 5, 23 and 46 for small, medium and large farm category, respectively. 


\section{Introduction}

India has vast resources of livestock, which play a vital role in improving the socioeconomic conditions of the rural masses. India's livestock sector is one of the largest in the world with a holding of 11 per cent of world livestock population. India ranks first in respect of buffalo population, contributing 56.70 per cent to the world's buffalo population (Patil et al., 2019). From 1951 to 2012 the absolute increase in buffalo population has been from 43.4 million to 108.70 million. In species wise meat contribution during the year 2018-19, the buffalo meat contributes 19.05 per cent and 13.30 lakh tonnes of buffalo meat annually exported by India. Tamil Nadu state has 518.80 thousands of buffalo population, of which 47.77 thousands male buffalo and 2.97 thousand tonnes of buffalo meat produced from slaughter of 21.4 thousands number of buffaloes (DAHDF, 2019). In 2012, the male calf population as compared to female calf population was just 53.6 per cent indicating the country level mortality in male buffalo calves about 50 per cent (Mendiratta and Kondaiah, 2015). There is a clear indication that the male calves are kept apathy and they are not fed properly and die before they reach one year of age.

In India, male buffalo calves are considered as burden and left as such as stray animals. The meat from such animals if reared properly has great export potential (Jairath et al., 2017). It has been observed that in India every year about 10 millions of male buffalo calves are removed or killed from the production system by farmers due to their intentional negligence in the management practices with a view to save on mother's milk. Salvaging and rearing of male buffalo calves also provide more raw materials for the domestic leather industry and open up a new avenue for rural employment. The buffalo is now increasingly being recognized as meat animal owing to heavy demand of meat of buffalo claves (Kamboj et al., 2007).

The rearing of male buffalo calves for meat production is an economically viable enterprise as integration with crop and fodder in some districts of Tamil Nadu near by border state of Kerala, viz., Coimbatore, Theni and Kanyakumari. The farmers earn good income by rearing these calves up to a suitable age and then sell them to meat industry and utilize the dung and urine as manure viz., fodder wastages used as feeding for calves. Kearala, nearby state to Tamil $\mathrm{Nadu}$ is providing big opportunity for male buffalo calves meat sales. Rearing of male buffalo calves provides enough organic manure and helps reducing fertilizer cost. Once, the rearers' start get sizable economic return through the sale of their male calves, the present practice of negligence towards them will gradually stop. The result of this study, as it quantifies the cost and returns will aid the researchers, planners and policy makers to design suitable policy implications. Further, with the information provided by this study will be helpful to increase returns and reduce expenses. It may be concluded that rearing of neglected male buffalo calves for meat production is more profitable. With these entire sources, the present study was carried out with the general objective of analysing the cost and returns of male buffalo calves farming for meat production in Coimbatore, Theni and Kanyakumari districts of Tamil Nadu.

\section{Materials and Methods}

Coimbatore, Theni and Kanyakumari districts of Tamil Nadu State were purposively selected for the present study, as these districts was more in terms of male buffaloe calves rearing farms along with cultivation of fodder crops and coconut trees. The male 
buffalo calves rearing activities are much familiar with livestock farmer those who are in near by Kerala border and the high demand for male calves by meat industries which are located in around Kerala State.

\section{Sampling framework}

A simple random sampling technique was adopted to select the sample villages and male buffalo calves rearing farmers in selected districts. Coimbatore, Theni and Kanyakumari districts of Tamil Nadu State were purposively selected. From each of the selected districts, 20 male buffalo calves rearer were selected randomly, covering a total of 60 male buffalo calves farmers for this study. The data were collected from all the categories of the farmers and were categorized as small, medium and large based on their number of animal holding and analysis based on these categories.

\section{Period of study}

From the male buffalo calves rearing farmers so selected, relevant data pertaining to the period of two years (2018-19 and 2019-20) were collected to achieve the objectives of the study. The data were collected during the months of August 2019 and March 2020.

\section{Method of enquiry and data collection}

From the selected farmers, relevant data were collected so as to achieve the objectives of this study. For this purpose, structured and pretested interview schedules were used.

The data were collected by personal interview method. Information on purchase price of calves, herd size, housing and equipment details, type of labour engaged, expenses regarding feed and fodder, cultivation charges, deworming, vaccination and veterinary charges, electricity charges, investment particulars including depreciation and fixed capital interest and revenue details such as sale price of calves and revenue from manure were collected from the sample respondents.

\section{Tools of analysis}

The following statistical tools were used for the analysis and interpretation of the data.

\section{Descriptive statistics}

After collecting the data, the data were analyzed in a form of frequencies and percentages.

\section{Method of calculation of cost and returns}

Cost components in male buffalo calves farming include fixed investment, fixed, variable and gross cost. In fixed investment, cost of shed, chaff cutter and equipment, electrical installations of the farm area were taken into account to work out the capital investment.

Fixed cost included the depreciation on building (10 per cent), equipment (10 per cent) and interest on fixed investment (12 per cent). Variable cost including cost of purchase of calves, concentrate feed, dry fodder and green fodder, fodder cultivation charges, wages for labour, medicine, deworming charges, vaccination and veterinary charges, electricity charges and miscellaneous cost were calculated. Total cost comprised of fixed cost and variable cost components.

Gross return per farm and per animal was calculated by adding returns from sale of male buffalo calves and manure. Net return per farm and per animal for small, medium and large were calculated by deducting the total cost of inputs from total returns. The analysis included small, medium and large holdings, in 
order to have a greater variation of the cost parameters under examination. This is important to note because the cost components refer to a broad and general range of rearing practices belonging to this area. Therefore, the conclusions will pertain to the male buffalo calves rearing sector as a whole and not to particular farm size categories.

\section{Profitability measures}

\section{Benefit cost ratio}

Benefit cost ratio was computed by dividing the gross receipts by total cost of inputs. Benefit cost ratio is useful in evaluating the worth of investment made in the farm.

Benefit cost ratio $=\frac{\text { Gross receipts }}{\text { Total cost of inputs }}$

\section{Break even analysis}

Break even analysis was done to work out the minimum herd size on all categories of farms which would just be sufficient to cover the cost of production.

Break even output $=$

Fixed cost

Price per unit of output-variable cost per unit of output

\section{Margin of safety}

The margin of safety of a farmer is the difference between its normal capacity and break even output. Margin of safety indicates the shock absorbing capacity of the farmer in times of risk and uncertainty. In other words it reflects the financial strength of the enterprise.

Margin of safety $=$ Normal capacity - Break even output

\section{Results and Discussion}

\section{Average fixed investment}

Details of various investments made in selected male buffalo calves farming in the study area are displayed in table 1 . In medium and large farms investment on construction of shed for animals contributed maximum as more than eighty per cent to total investment followed by investment on equipment viz., concrete feeding trough, waterer and rope for tying the animals as more than twelve per cent and lastly investment on chaff cutter in large farms nearly three per cent only. Major components of total investment in large per farm was construction of shed (85.02 per cent), followed by purchase of equipment (12.12 per cent) and investment on chaff cutter (2.83 per cent), in per animal the investment on shed and equipment were 87.91 per cent and 12.09 per cent. In medium category, per farm and per animal investment on shed were (87.50 per cent) and equipment (12.50 per cent). The results explains the fact that as the farm size increases investment per animal decreases, were the large farms were doing bulk purchase and getting maximum discount price for the equipment and also reduction in transport cost. In small farms the farmer made investment only on equipment as contributed hundred per cent.

\section{Average fixed cost}

Average fixed cost in male buffalo calves farming are portrayed in table 1. On an average, share of fixed cost components including interest on fixed investment, depreciation on shed and depreciation on equipments towards total fixed cost in large farm category for per farm was 83.63 per cent, 5.93 per cent and 10.44 per cent, respectively and per animal was 57.38 per cent, 42.04 per cent and 0.58 per cent, respectively. Total fixed cost per farm is 
higher in medium farm (6.75 per cent), large farm (4.71 per cent) and small farm (00.10 per cent). The total fixed cost contribution per animal is higher in large farm (6.53 per cent) followed by medium farm (4.72 per cent) and small farm (00.08 per cent).

\section{Average variable cost}

Table 1 displays the average variable cost for small, medium and large farm incurred in male buffalo calves farming. Fig. 1 to Fig. 4 shows share of different mechanism of variable cost in per cent in all category of farms. Among the components of variable cost in male buffalo calves rearing for per farm in small category, the cost of bull calves (69.78 per cent) contributes higher share followed by cost of concentrate (25.57 per cent), cost of dry fodder ( 2.55 per cent), cost of deworming (1.40 per cent) and miscellaneous charges $(0.70$ per cent). For per animal components in small farm category of variable components were the cost of bull calves contributes higher per centage share of 68.81 followed by cost of concentrate was 26.59 per cent, cost of dry fodder was 2.52 per cent, cost of deworming was 1.38 per cent and miscellaneous charges were 0.69 per cent. Govindarajulu and Lakshmipathi (1998) reported that the feeding cost accounted for approximately 80 per cent of the total cost of buffalo meat production.

Average variable costs incurred per animal in medium farm was higher in cost of bull calves (68.43 per cent), followed by cost of concentrate (26.06 per cent), cost of green fodder cultivation ( 0.12 per cent), cost of dry fodder (1.96 per cent), labour wages (1.13 per cent), deworming charges (1.43 per cent), Vaccination charges (0.14 per cent), electricity expenses $(0.01$ per cent $)$ and miscellaneous charges $(0.71$ per cent). For per animal expenses components for large farm category was 67.49 per cent for cost of bull calves followed by 26.08 per cent for cost of concentrate feeding, 0.31 per cent for charges on cultivation of green fodder, 1.91 per cent for dry fodder, 1.85 per cent for payment of wages for labour, 1.47 per cent towards purchase of deworming medicine, 0.15 per cent for vaccination charges, 0.02 per cent for electricity expenses and finally 0.73 per cent for unexpected or miscellaneous expenses. The feeding and labour charges were the major components of cost accounting for 71.00 per cent to 88.70 per cent of the total cost of rearing at veal as well as at beef stage (Kamboj et al., 2007).

\section{Average total cost}

Table 1 portrays the average total cost computation for small, medium and large farm category for rearing male buffalo calves. For per farm category, the total cost was higher in large farm (Rs.7,51,957.20), followed by medium farm (Rs.3,71,030.60) and for small farm (Rs.1,07,187.30). Among the total cost, the total variable cost for per farm was 95.29 per cent, 93.25 per cent and 99.90 per cent for large, medium and small farm category, respectively. The total fixed cost contribution was 6.75 per cent (medium), 4.71 per cent (large) and 00.10 per cent (small).

For per animal, the total cost was higher in medium farm (Rs.14,698.68), followed by large farm (Rs.14,563.66) and for small farm (Rs.14,487.90). Among the total cost, the total variable cost for per animal was 99.92 per cent, 95.28 per cent and 93.47 per cent for small, medium and large farm category, respectively. The total fixed cost contribution was 6.53 per cent (large), 4.72 per cent (medium) and 00.08 per cent (small). 
Table.1 Cost and returns in male buffalo calves farming (in rupees)

\begin{tabular}{|c|c|c|c|c|c|c|c|}
\hline \multicolumn{2}{|r|}{ Components } & \multicolumn{2}{|c|}{ Small } & \multicolumn{2}{|c|}{ Medium } & \multicolumn{2}{|c|}{ Large } \\
\hline & & $\begin{array}{l}\text { Per } \\
\text { farm }\end{array}$ & $\begin{array}{c}\text { Per } \\
\text { Animal }\end{array}$ & $\begin{array}{l}\text { Per } \\
\text { Farm }\end{array}$ & $\begin{array}{c}\text { Per } \\
\text { Animal }\end{array}$ & $\begin{array}{l}\text { Per } \\
\text { farm }\end{array}$ & $\begin{array}{c}\text { Per } \\
\text { animal }\end{array}$ \\
\hline \multirow[t]{5}{*}{ A. } & \multicolumn{7}{|l|}{ Fixed investment } \\
\hline & Cost of shed & $\begin{array}{l}00.00 \\
(0.00)\end{array}$ & $\begin{array}{l}00.00 \\
(0.00)\end{array}$ & $\begin{array}{l}105000.00 \\
(87.50)\end{array}$ & $\begin{array}{l}4200.00 \\
(87.50)\end{array}$ & $\begin{array}{l}210000.00 \\
(85.02)\end{array}$ & $\begin{array}{c}4000.00 \\
(87.91)\end{array}$ \\
\hline & Cost of chaff cutter & $\begin{array}{l}00.00 \\
(0.00)\end{array}$ & $\begin{array}{l}00.00 \\
(0.00)\end{array}$ & $\begin{array}{l}00.00 \\
(0.00)\end{array}$ & $\begin{array}{l}00.00 \\
(0.00)\end{array}$ & $\begin{array}{c}7000.00 \\
(2.83)\end{array}$ & $\begin{array}{l}00.00 \\
(0.00)\end{array}$ \\
\hline & Cost of equipment & $\begin{array}{c}500.00 \\
(100.00)\end{array}$ & $\begin{array}{c}50.00 \\
(100.00)\end{array}$ & $\begin{array}{c}15000.00 \\
(12.50)\end{array}$ & $\begin{array}{l}600.00 \\
(12.50)\end{array}$ & $\begin{array}{l}30000.00 \\
(12.15)\end{array}$ & $\begin{array}{l}550.00 \\
(12.09)\end{array}$ \\
\hline & $\begin{array}{l}\text { Total Fixed } \\
\text { Investment }\end{array}$ & $\begin{array}{l}500.00 \\
(100.00)\end{array}$ & $\begin{array}{c}50.00 \\
(100.00)\end{array}$ & $\begin{array}{l}120000.00 \\
(100.00)\end{array}$ & $\begin{array}{l}4800.00 \\
(100.00)\end{array}$ & $\begin{array}{c}247000.00 \\
(100.00)\end{array}$ & $\begin{array}{l}4550.00 \\
(100.00)\end{array}$ \\
\hline \multirow[t]{5}{*}{ B. } & \multicolumn{7}{|l|}{ Fixed Cost } \\
\hline & $\begin{array}{l}\text { Interest on fixed } \\
\text { investment } 12 \%\end{array}$ & $\begin{array}{c}60.00 \\
(54.55)\end{array}$ & $\begin{array}{c}6.00 \\
(54.55)\end{array}$ & $\begin{array}{c}14400.00 \\
(57.49)\end{array}$ & $\begin{array}{l}576.00 \\
(83.04)\end{array}$ & $\begin{array}{c}29640.00 \\
(83.63)\end{array}$ & $\begin{array}{l}546.00 \\
(57.38)\end{array}$ \\
\hline & $\begin{array}{l}\text { Depreciation on shed } 10 \\
\%\end{array}$ & $\begin{array}{c}0.00 \\
(00.00)\end{array}$ & $\begin{array}{c}0.00 \\
(00.00)\end{array}$ & $\begin{array}{c}10500.00 \\
(41.92)\end{array}$ & $\begin{array}{l}57.60 \\
(8.30)\end{array}$ & $\begin{array}{c}2100.00 \\
(5.93)\end{array}$ & $\begin{array}{l}400.00 \\
(42.04)\end{array}$ \\
\hline & $\begin{array}{l}\text { Depreciation on } \\
\text { equipment } 10 \%\end{array}$ & $\begin{array}{c}50.00 \\
(45.45)\end{array}$ & $\begin{array}{c}05.00 \\
(45.45)\end{array}$ & $\begin{array}{c}150.00 \\
(0.60)\end{array}$ & $\begin{array}{l}60.00 \\
(8.65)\end{array}$ & $\begin{array}{l}3700.00 \\
(10.44)\end{array}$ & $\begin{array}{l}05.50 \\
(0.58)\end{array}$ \\
\hline & Total Fixed Cost & $\begin{array}{c}110.00 \\
(\mathbf{1 0 0 . 0 0}) \\
(\mathbf{0 0 . 1 0})^{\mathbf{c}}\end{array}$ & $\begin{array}{c}11.00 \\
(\mathbf{1 0 0 . 0 0}) \\
(\mathbf{0 0 . 0 8})^{\mathbf{c}}\end{array}$ & $\begin{array}{c}25050.00 \\
(\mathbf{1 0 0 . 0 0 )}) \\
(\mathbf{6 . 7 5})^{\mathrm{c}}\end{array}$ & $\begin{array}{c}693.60 \\
(\mathbf{1 0 0 . 0 0 )}) \\
(\mathbf{4 . 7 2})^{\mathbf{c}}\end{array}$ & $\begin{array}{c}35440.00 \\
(\mathbf{1 0 0 . 0 0}) \\
\mathbf{( 4 . 7 1 )}^{\mathbf{c}}\end{array}$ & $\begin{array}{c}951.50 \\
(\mathbf{1 0 0 . 0 0}) \\
(\mathbf{6 . 5 3})^{\mathbf{c}}\end{array}$ \\
\hline \multirow[t]{11}{*}{ C. } & \multicolumn{7}{|l|}{ Variable Cost } \\
\hline & Cost of bull calves & $\begin{array}{c}74714.29 \\
(69.78)\end{array}$ & $\begin{array}{l}9961.90 \\
(68.81)\end{array}$ & $\begin{array}{l}165942.90 \\
(47.96)\end{array}$ & $\begin{array}{l}9584.16 \\
(68.43)\end{array}$ & $\begin{array}{l}398363.60 \\
(55.60)\end{array}$ & $\begin{array}{r}9186.58 \\
(67.49)\end{array}$ \\
\hline & Cost of concentrate & $\begin{array}{c}27375.50 \\
(25.57)\end{array}$ & $\begin{array}{l}3850.00 \\
(26.59)\end{array}$ & $\begin{array}{c}63197.14 \\
(18.27)\end{array}$ & $\begin{array}{l}3650.00 \\
(26.06)\end{array}$ & $\begin{array}{l}158277.27 \\
(22.09)\end{array}$ & $\begin{array}{c}3550.00 \\
(26.08)\end{array}$ \\
\hline & $\begin{array}{l}\text { Cost of Fodder } \\
\text { cultivation }\end{array}$ & $\begin{array}{c}0.00 \\
(0.00)\end{array}$ & $\begin{array}{c}0.00 \\
(0.00)\end{array}$ & $\begin{array}{c}10000.00 \\
(2.89)\end{array}$ & $\begin{array}{l}16.51 \\
(0.12)\end{array}$ & $\begin{array}{c}20000.00 \\
(2.79)\end{array}$ & $\begin{array}{l}41.92 \\
(0.31)\end{array}$ \\
\hline & Cost of dry fodder & $\begin{array}{c}2737.50 \\
(2.55)\end{array}$ & $\begin{array}{c}365.00 \\
(2.52)\end{array}$ & $\begin{array}{c}4700.00 \\
(1.36)\end{array}$ & $\begin{array}{c}275.00 \\
(1.96)\end{array}$ & $\begin{array}{c}5000.00 \\
(0.70)\end{array}$ & $\begin{array}{c}260.00 \\
(1.91)\end{array}$ \\
\hline & Labour wages & $\begin{array}{c}0.00 \\
(0.00)\end{array}$ & $\begin{array}{c}0.00 \\
(0.00)\end{array}$ & $\begin{array}{c}96000.00 \\
(27.75)\end{array}$ & $\begin{array}{l}158.42 \\
(1.13)\end{array}$ & $\begin{array}{c}120000.00 \\
(16.75)\end{array}$ & $\begin{array}{l}251.57 \\
(1.85)\end{array}$ \\
\hline & Cost of Deworming & $\begin{array}{c}1500.00 \\
(1.40)\end{array}$ & $\begin{array}{c}200.00 \\
(1.38)\end{array}$ & $\begin{array}{c}3462.86 \\
(1.00)\end{array}$ & $\begin{array}{c}200.00 \\
(1.43)\end{array}$ & $\begin{array}{c}8672.72 \\
(1.21)\end{array}$ & $\begin{array}{c}200.00 \\
(1.47)\end{array}$ \\
\hline & Cost of Vaccination & $\begin{array}{c}0.00 \\
(0.00)\end{array}$ & $\begin{array}{c}0.00 \\
(0.00)\end{array}$ & $\begin{array}{c}346.28 \\
(0.10)\end{array}$ & $\begin{array}{l}20.00 \\
(0.14)\end{array}$ & $\begin{array}{l}867.27 \\
(0.12)\end{array}$ & $\begin{array}{l}20.00 \\
(0.15)\end{array}$ \\
\hline & Cost of Electricity & $\begin{array}{c}0.00 \\
(0.00)\end{array}$ & $\begin{array}{c}0.00 \\
(0.00)\end{array}$ & $\begin{array}{l}600.00 \\
(0.17)\end{array}$ & $\begin{array}{c}0.99 \\
(0.01)\end{array}$ & $\begin{array}{c}1000.00 \\
(0.14)\end{array}$ & $\begin{array}{c}2.09 \\
(0.02)\end{array}$ \\
\hline & Miscellaneous charges & $\begin{array}{c}750.00 \\
(0.70)\end{array}$ & $\begin{array}{c}100.00 \\
(0.69)\end{array}$ & $\begin{array}{c}1731.43 \\
(0.50)\end{array}$ & $\begin{array}{c}100.00 \\
(0.71)\end{array}$ & $\begin{array}{c}4336.36 \\
(0.61)\end{array}$ & $\begin{array}{l}100.00 \\
(0.73)\end{array}$ \\
\hline & Total Variable Cost & $\begin{array}{c}107077.30 \\
(\mathbf{1 0 0 . 0 0 )} \\
(\mathbf{9 9 . 9 0})^{\mathbf{c}}\end{array}$ & $\begin{array}{l}14476.9 \\
(\mathbf{1 0 0 . 0 0 )} \\
(\mathbf{9 9 . 9 2})^{\mathbf{c}}\end{array}$ & $\begin{array}{c}345980.6 \\
(\mathbf{1 0 0 . 0 0 )} \\
(\mathbf{9 3 . 2 5})^{\mathbf{c}}\end{array}$ & $\begin{array}{c}14005.08 \\
(\mathbf{1 0 0 . 0 0 )} \\
(\mathbf{9 5 . 2 8})^{\mathbf{c}}\end{array}$ & $\begin{array}{c}716517.20 \\
(\mathbf{1 0 0 . 0 0 )} \\
(\mathbf{9 5 . 2 9})^{\mathbf{c}}\end{array}$ & $\begin{array}{c}13612.16 \\
(\mathbf{1 0 0 . 0 0 )} \\
(\mathbf{9 3 . 4 7})^{\mathbf{c}}\end{array}$ \\
\hline D. & Total Cost $(A+B)$ & $\begin{array}{r}107187.30 \\
(\mathbf{1 0 0 . 0 0})^{\mathrm{c}}\end{array}$ & $\begin{array}{l}14487.90 \\
(\mathbf{1 0 0 . 0 0})^{\mathrm{c}}\end{array}$ & $\begin{array}{c}371030.60 \\
(\mathbf{1 0 0 . 0 0})^{\mathbf{c}}\end{array}$ & $\begin{array}{l}14698.68 \\
(\mathbf{1 0 0 . 0 0})^{\mathrm{c}}\end{array}$ & $\begin{array}{c}751957.20 \\
(\mathbf{1 0 0 . 0 0})^{\mathbf{c}}\end{array}$ & $\begin{array}{l}14563.66 \\
(\mathbf{1 0 0 . 0 0})^{\mathrm{c}}\end{array}$ \\
\hline \multirow[t]{4}{*}{ E. } & \multicolumn{7}{|l|}{ Returns } \\
\hline & Sale of animals & $\begin{array}{c}130142.90 \\
(99.55)\end{array}$ & $\begin{array}{c}21951.81 \\
(99.55)\end{array}$ & $\begin{array}{c}478028.60 \\
(99.62)\end{array}$ & $\begin{array}{c}26431.28 \\
(99.62)\end{array}$ & $\begin{array}{c}1207727.00 \\
(99.64)\end{array}$ & $\begin{array}{c}27335.39 \\
(99.64)\end{array}$ \\
\hline & Sale of Manure & $\begin{array}{c}592.85 \\
(0.45)\end{array}$ & $\begin{array}{c}100.00 \\
(0.45)\end{array}$ & $\begin{array}{c}1808.57 \\
(0.38)\end{array}$ & $\begin{array}{c}100.00 \\
(0.38)\end{array}$ & $\begin{array}{c}4418.18 \\
(0.36)\end{array}$ & $\begin{array}{c}100.00 \\
(0.36)\end{array}$ \\
\hline & Gross Return & $\begin{array}{c}130735.80 \\
(\mathbf{1 0 0 . 0 0 )}\end{array}$ & $\begin{array}{c}22051.81 \\
(\mathbf{1 0 0 . 0 0 )}\end{array}$ & $\begin{array}{c}479837.20 \\
(\mathbf{1 0 0 . 0 0 )}\end{array}$ & $\begin{array}{c}26531.28 \\
\text { (100.00) }\end{array}$ & $\begin{array}{c}1212145.00 \\
(\mathbf{1 0 0 . 0 0})\end{array}$ & $\begin{array}{c}27435.39 \\
(\mathbf{1 0 0 . 0 0 )}\end{array}$ \\
\hline F. & Net Return & 23548.46 & 7563.91 & 108806.60 & 11832.6 & 460188.00 & 12871.73 \\
\hline
\end{tabular}

Figures in parentheses indicate percentages to the respective total

Figures in parentheses indicate percentages to the total cost 
Table.2 Profitability measures of male buffalo calves rearing (in numbers)

\begin{tabular}{|l|c|c|c|}
\hline \multicolumn{1}{|c|}{ Particulars } & Small & Medium & Large \\
\hline Benefit Cost Ratio & 1.22 & 1.29 & 1.40 \\
\hline Break Even Output (in numbers) & 3 & 17 & 39 \\
\hline Margin of Safety (in numbers) & 2 & 12 & 25 \\
\hline
\end{tabular}

Fig.1 Variable cost component in small farming (in per cent)

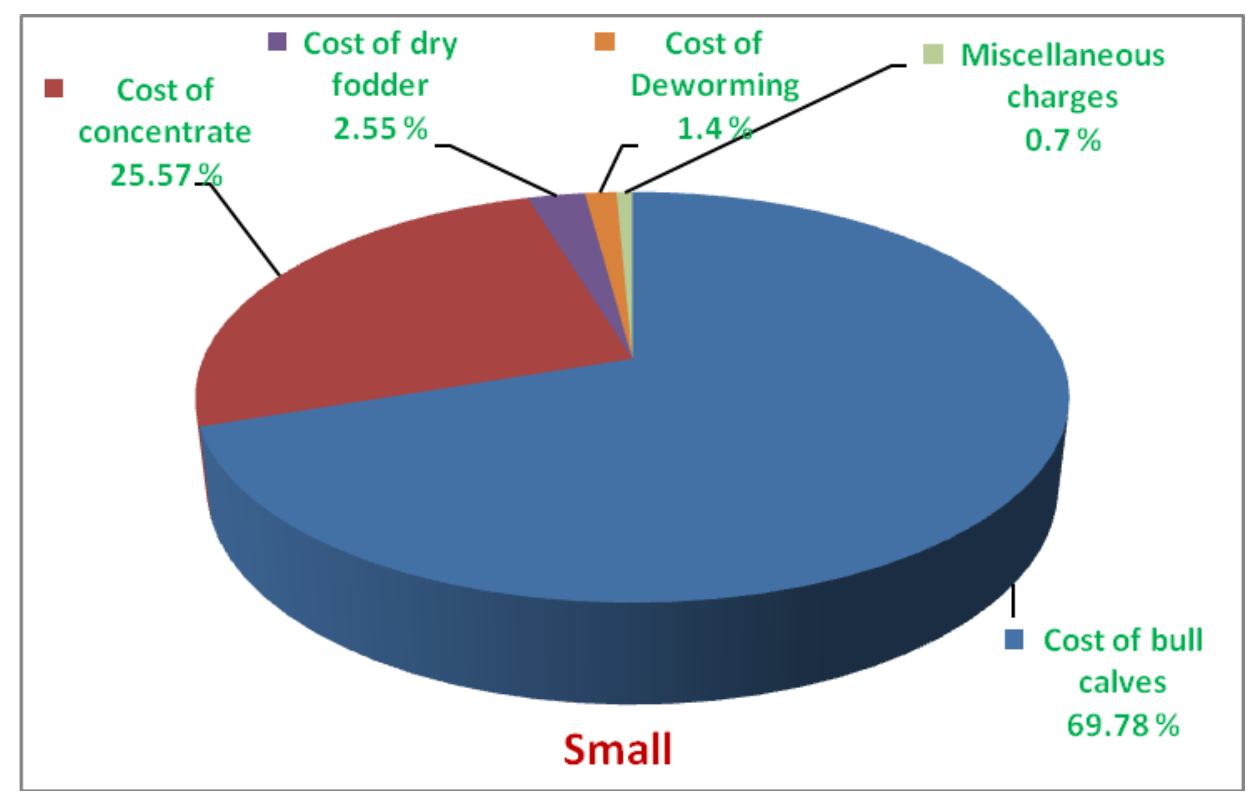

Fig.2 Variable cost component in medium farming (in per cent)

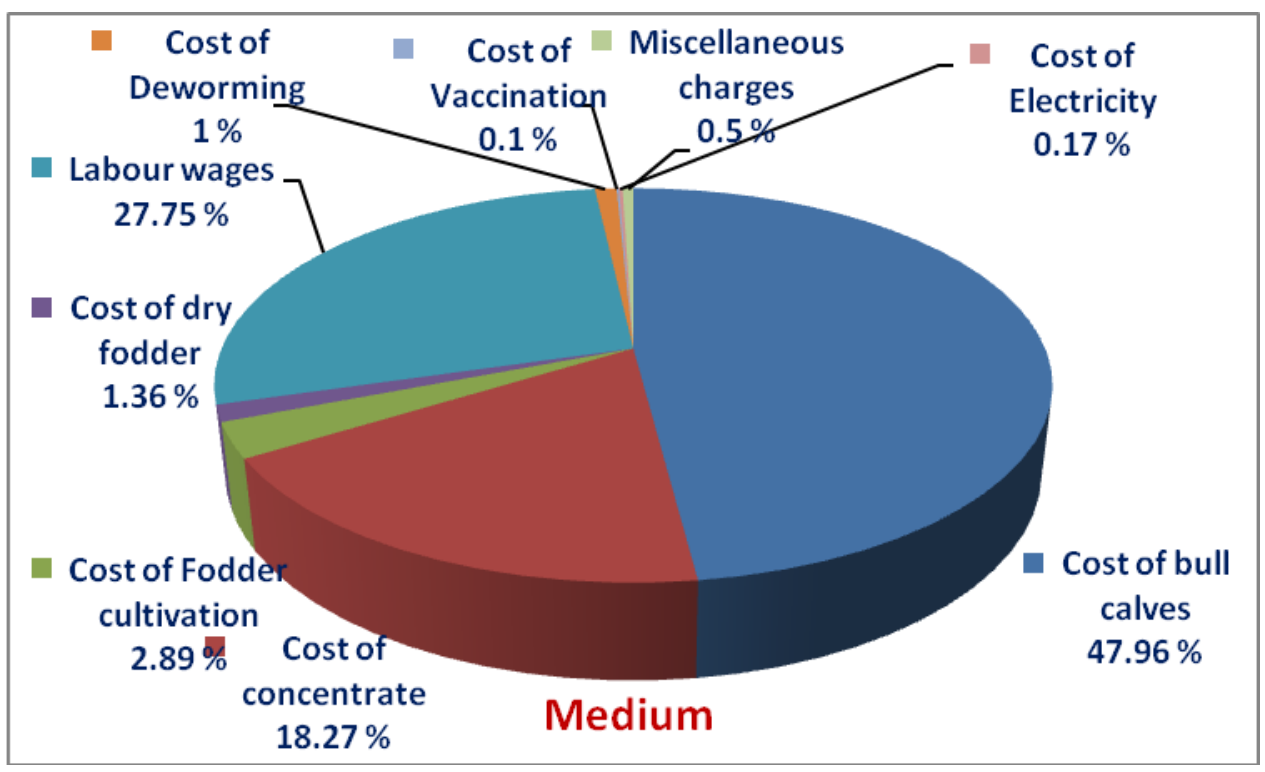


Fig.3 Variable cost component in large farming (in per cent)

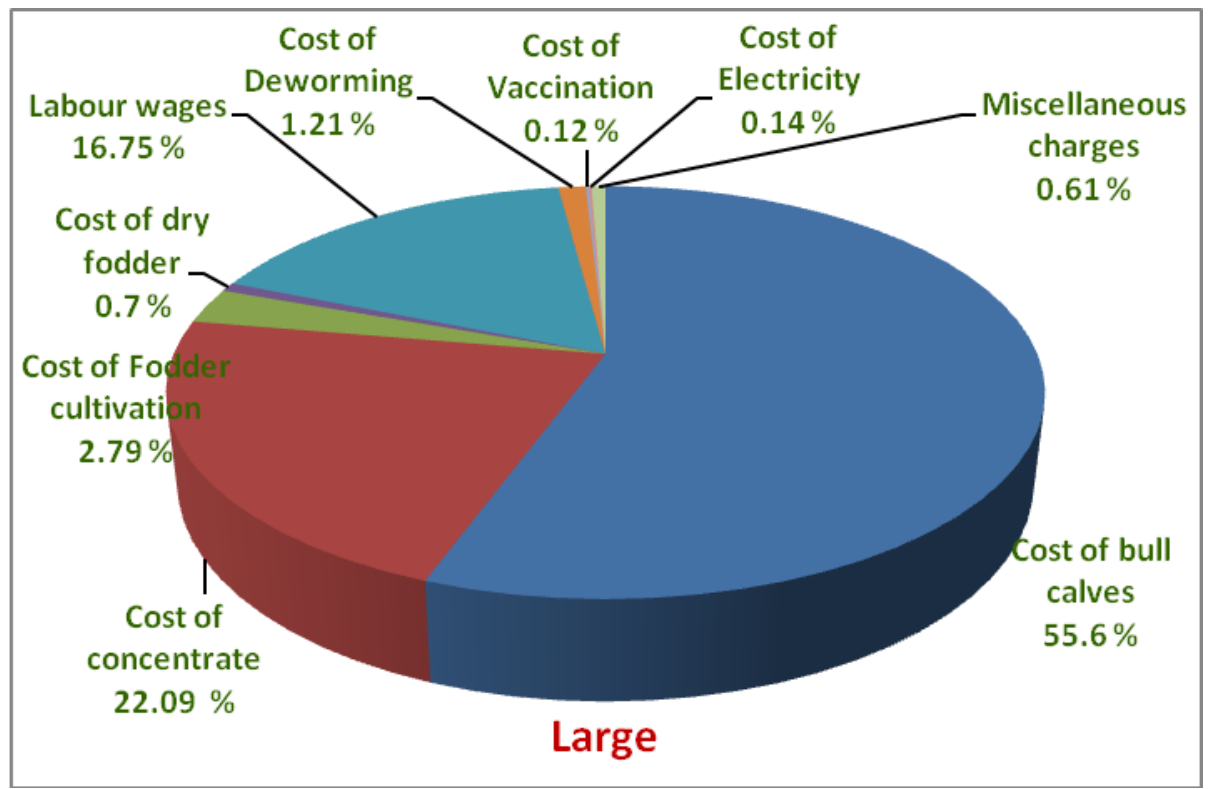

Fig.4 Variable cost component in overall farming (in per cent)

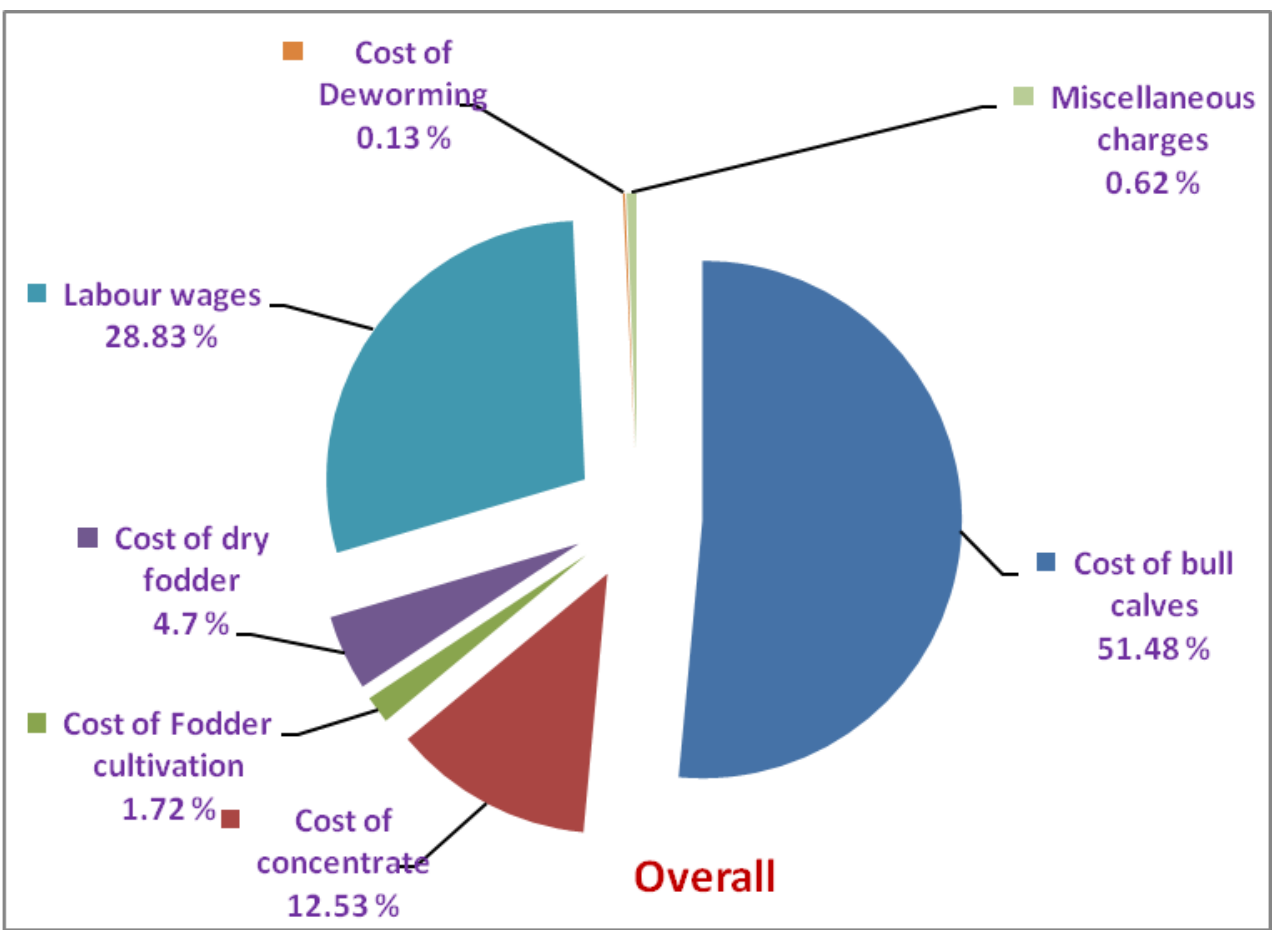


Fig.5 Average net return per farm in male buffalo calves rearing per annum in rupees

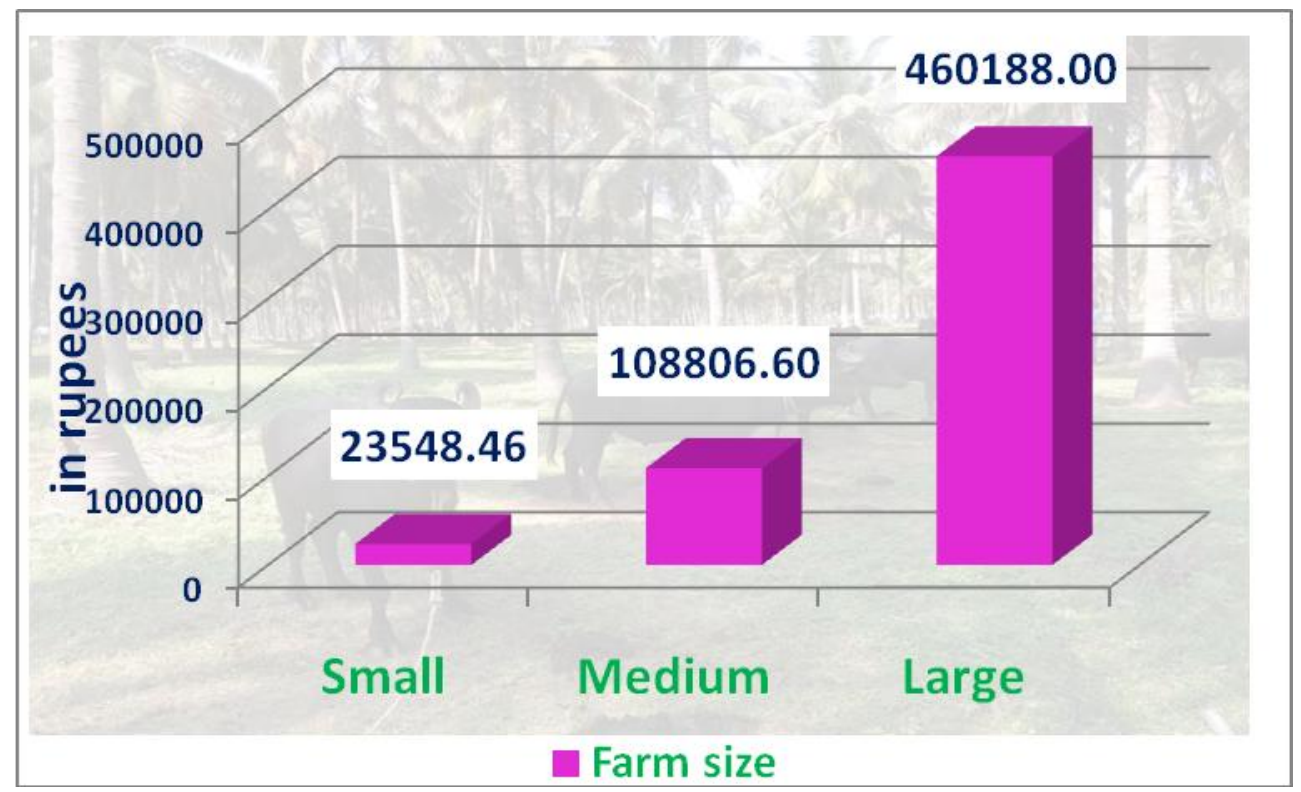

Fig.6 Average net return per animal in male buffalo calves rearing per annum in rupees

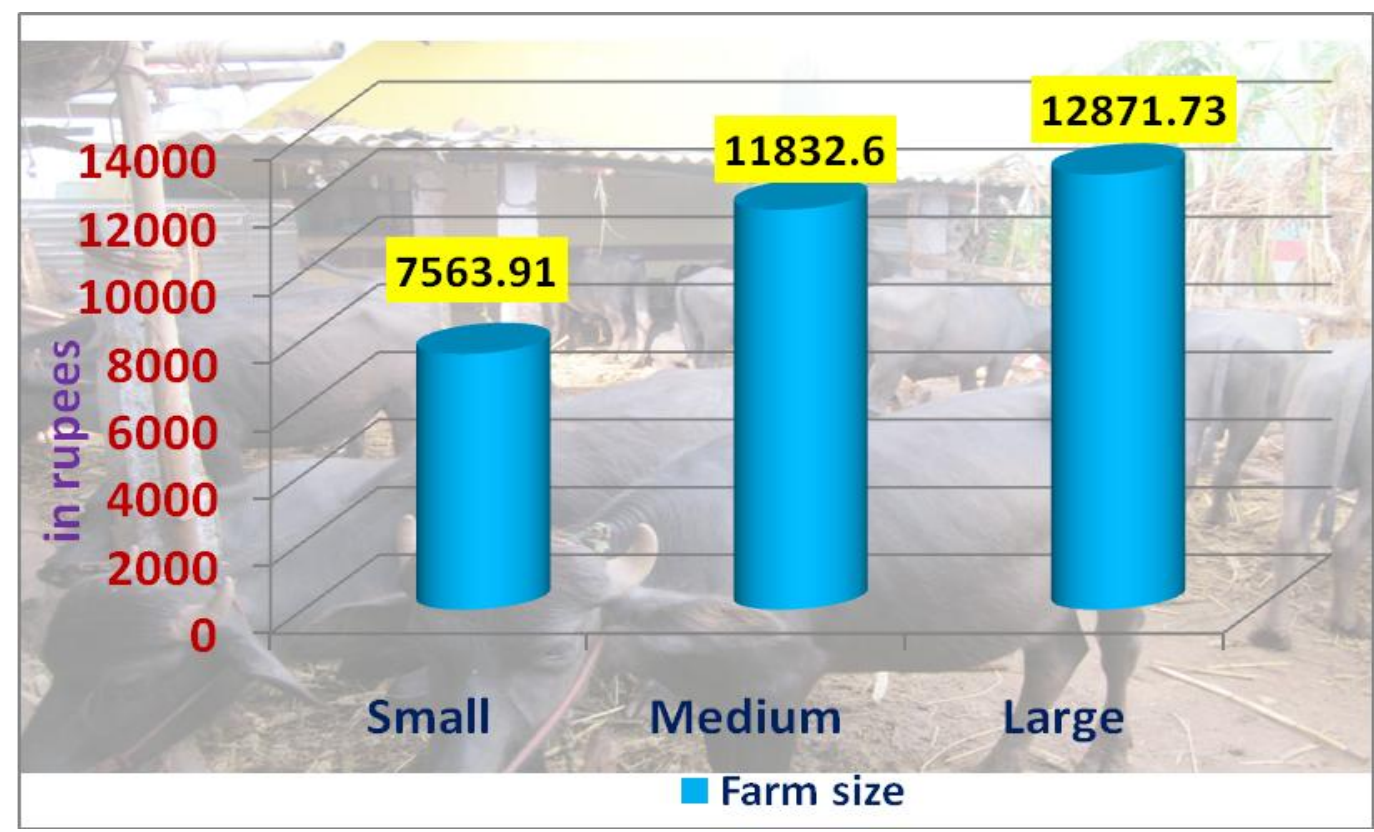

Kamboj et al., (2007) reported that the other components of cost viz., veterinary and animal healthcare charges, interest on fixed capital, depreciation on shed and miscellaneous expenses contributed only a minor percentage ( 0.2 to 4.3$)$ of total cost both at veal and beef stage of rearing.

\section{Gross return}

Gross returns for small, medium and large farm for per farm and per animal were calculated and portrayed in table 1. By sale of animals were contributed more than 99.50 per cent to the total returns and the remaining 
0.50 per cent was contributed by sale or imputed use of manure. Gross return for per farm in large, medium and small were Rs.12,12,145.00, Rs.4,79,837.20 and Rs.1,30,735.80, respectively. For per animal gross return in large, medium and small were Rs.27,435.39, Rs.26,531.28 and Rs.22,051.81, respectively.

\section{Net return}

From the table 1 it was found that net return per farm was Rs.4,60,188.00 (large), Rs.1,08,806.60 (medium) and Rs.23,548.46 (small). Fig. 5 shows the average net return per farm in male buffalo calves rearing per annum in rupees. Net return per animal in large farm was Rs.12,871.73, medium farm for Rs.11,832.60 and small farm for Rs.7,563.91 (Fig. 6). The result explains the fact of economies of scale where net return increases with increase in farm size which optimises the utilization of factors of production.

\section{Benefit cost ratio}

From the table 2, it could be found that the benefit cost ratio of male buffalo calves farming was $1: 1.22,1: 1.29$ and $1: 1.40$ in small, medium and large farms, respectively. The benefit cost ratio was higher in large farms followed by medium and small farms. It is understood that the benefit cost ratio increases with increase in farm size which implies the concept of economies of scale. Islam et al., (2017) reported that the benefit cost ratio was calculated $1: 1.31$ in profitability measures on rearing of buffalo.

\section{Break even output}

The break even output obtained for male buffalo calves rearing is presented in table 2 . Break even output in small, medium and large farms were 3, 17 and 39 animals, respectively while the average output were 5, 23 and 46, respectively. It is concluded from the table that break even output were lower than the respective average output which indicates that the farms were running profitably.

\section{Margin of safety}

Margin of safety in male buffalo calves rearing (Table 2) in terms of number of animals were 2, 12 and 25 animals, which indicates that margin of safety is higher in large farms than medium and small farms. Margin of safety is awfully low in small farms in spite of which the benefit cost ratio was higher as they were employing only family labour.

In conclusion, the study revealed that the fact of economies of scale where net return and benefit cost ratio increases with increase in farm size which optimises the utilization of factors of production. The average break even output was 23 in medium size category of farms. By sale of animals were contributed more than 99.50 per cent to the total returns and the remaining 0.50 per cent was contributed by sale or imputed use of manure.

Average variable costs incurred per animal in medium farm were higher in cost of bull calves (68.43 per cent). The total fixed cost contribution per animal is higher in large farm (6.53 per cent). It was found that net return per farm was Rs.1,08,806.60 and for per animal was Rs.11,832.60 in medium category farm. Suggestions and policy implications are i)Create awareness among the farmers regarding the viability of this male buffalo calves enterprise especially those who are nearby Kerala border area, hence the high demand from Kerala meat industries. ii) Increase the profitability in the farm, advise the farmers to adopt scientific management practices and to get the maximum profit. 


\section{References}

DAHDF (2019). Basic Animal Husbandry Statistics-part 2. Department of Animal Husbandry Dairying and Fisheries, New Delhi, India, Pp. 1-165.

Govindarajulu, $\mathrm{M}$ and V. Lakshmipathi (1998). In. Proc. $2^{\text {nd }}$ world buffalo congress, New Delhi, Vol. IV, Pp. 393396.

Islam. S., T.T. Nahar, J. Begum, G.K. Deb, M. Khatun and A. Mustafa (2017). Economic evaluation of buffalo production in selected regions of Bangladesh. Journal of Stock and Forex Trading, Vol 6(1): 177.

Jairath G., D.P.Sharma, R.S. Dabur (2017). Buffalo calf: an emerging meat source in India. MOJ Food Processing and
Technology, Vol.5 (3): 318-319.

Kamboj, M.L., S.S. Paul, D.S. Chawla and Shiv Prasad. (2007). Economics of rearing Nili-ravi male buffalo calves under four feeding regimes for meat production. Indian Journal of Animal Research, Vol. 41 (3):200-203.

Mendiratta, S.K and N. Kondaiah (2015). Male buffalo calves - Potential benefits of neglected wealth. Trends in Veterinary and Animal Sciences, Vol.2: 05-10.

Patil Vinayak, B.S. Reddy, S.S. Patil and G.M. Hiremath. (2019). Comparative economics of rural and periurban dairy farming in Kalaburagi district of Karnataka. Journal of Applied and Natural Science, Vol.11 (4): 762-767.

\section{How to cite this article:}

Senthilkumar, V., V. Palanichamy and Chitra, R. 2020. Economic Analysis of Cost and Returns in Male Buffalo Calves Farming for Meat Production in Selected Districts of Tamil Nadu, India. Int.J.Curr.Microbiol.App.Sci. 9(09): 1994-2004. doi: https://doi.org/10.20546/ijcmas.2020.909.249 